\title{
ANALYSIS STUDY OF THE COMPARATIVE QUALITY OF PATIENT SERVICES BEFORE AND AFTER COVID-19 PANDEMIC IN INSTALLATION OF SILOAM HOSPITAL TB SIMATUPANG INSTALLATION
}

\author{
Dian Agnesa Sembiring1), Atik Nurwahyuni²), Wahyu Sulistiadi²) \\ ${ }^{1)}$ Study of Hospital Administration, Faculty of Public Health, Universitas Indonesia \\ 2)Faculty of Public Health, Universitas Indonesia
}

\begin{abstract}
Background: In the COVID-19 (Coronavirus Disease 2019) pandemic crisis that has hit Indonesia since early March 2020, urgent action is needed to overcome the situation while maintaining and improving relationships with customers so that they are still satisfied with the quality of services in hospitals, especially inpatient services. Since the COVID-19 pandemic, there has been a significant decrease in the number of inpatient visits at Siloam Hospitals TB Simatupang. This study aimed to analyze the comparison of the level of quality of patient service before and after the COVID-19 pandemic in installation of Siloam hospital TB Simatupang installation.

Subjects and Method: This was a descriptive observational study conducted at Siloam Hospitals TB Simatupang from September 2020. A sample of 88 patients was selected by purposive sampling. The data was collected by questionnaire. The operationalization of this research variable is service quality, which is measured from five dimensions, namely Tangibles, Reliability, Responsiveness, Assurance, and Empathy. The data analysis used a series of tests such as validity test, reliability test, descriptive statistics and independent sample T-test.

Results: During the COVID-19 pandemic, patients had a better perception than before the COVID-19 pandemic, it can be seen from service quality (Mean=4.11), while during the COVID-19 pandemic (Mean= 4.250).

Conclusion: Quality of services provided in outpatient installations during the COVID-19 pandemic is better than before the COVID-19.
\end{abstract}

Kata Kunci: service quality, covid-19, outpatient

\section{Correspondence:}

Dian Agnesa Sembiring. Magister Program in Hospital Administration. Faculty of Public Health, University of Indonesia, Depok, West Java. Email: dianagnesa17@gmail.com

The 7th International Conference on Public Health

Solo, Indonesia, November 18-19, 2020|338 https://doi.org/10.26911/the7thicph.04.23 